\title{
Anti-Obesity Effects of Dietary Calcium: The Evidence and Possible Mechanisms
}

\author{
Fenglin Zhang ${ }^{1,2}$, Jingjing Ye ${ }^{1,2}$, Xiaotong Zhu ${ }^{1,2}$, Lina Wang ${ }^{1,2}$, Ping Gao ${ }^{1,2}$, Gang Shu ${ }^{1,2}$, \\ Qingyan Jiang ${ }^{1,2}$ and Songbo Wang ${ }^{1,2, * \mathbb{B}}$ \\ 1 Guangdong Provincial Key Laboratory of Animal Nutrition Control, College of Animal Science, South China \\ Agricultural University, Guangzhou 510642, China; zfl771896317@163.com (F.Z.); \\ fengzhongyezi2009@163.com (J.Y.); xtzhu@scau.edu.cn (X.Z.); wanglina@scau.edu.cn (L.W.); \\ gaoping@scau.edu.cn (P.G.); shugang@scau.edu.cn (G.S.); qyjiang@scau.edu.cn (Q.J.) \\ 2 National Engineering Research Center for Breeding Swine Industry and ALLTECH-SCAU Animal Nutrition \\ Control Research Alliance, South China Agricultural University, Guangzhou 510642, China \\ * Correspondence: songbowang@scau.edu.cn; Tel./Fax: +86-20-85284901
}

Received: 18 April 2019; Accepted: 20 June 2019; Published: 23 June 2019

\begin{abstract}
Obesity is a serious health challenge worldwide and is associated with various comorbidities, including dyslipidemia, type 2 diabetes, and cardiovascular disease. Developing effective strategies to prevent obesity is therefore of paramount importance. One potential strategy to reduce obesity is to consume calcium, which has been implicated to be involved in reducing body weight/fat. In this review, we compile the evidence for the anti-obesity roles of calcium in cells, animals, and humans. In addition, we summarize the possible anti-obesity mechanisms of calcium, including regulation of (a) adipogenesis; (b) fat metabolism; (c) adipocyte (precursor) proliferation and apoptosis; (d) thermogenesis; (e) fat absorption and excretion; and (f) gut microbiota. Although the exact anti-obesity roles of calcium in different subjects and how calcium induces the proposed anti-obesity mechanisms need to be further investigated, the current evidence demonstrates the anti-obesity effects of calcium and suggests the potential application of dietary calcium for prevention of obesity.
\end{abstract}

Keywords: anti-obesity; calcium; adipogenesis; fat metabolism; proliferation and apoptosis; thermogenesis; fecal fat excretion; gut microbiota

\section{The Current Situation of Obesity and Its Adverse Effects}

Obesity, defined as excessive fat deposition, has become increasingly prevalent worldwide. Over the last 40 years, the prevalence rates of obesity in adults (defined as BMI over $30 \mathrm{~kg} / \mathrm{m}^{2}$ ) has been increasing at a rapid pace in both Western societies and developing countries, with the number of obese adults reaching 671 million in 2016 (390 million women and 281 million men) compared to 100 million in 1975 (69 million women and 31 million men) [1]. In addition, the prevalence of childhood obesity has increased steadily in the developed and developing countries [2]. For example, approximately one-third of children in America are overweight or obese [3,4]. A similar situation has occurred in China, with the prevalence of childhood overweight and obesity being about one in five $[5,6]$.

Obesity has become a major public health burden all over the world. It is now well established that obesity is able to progressively lead to and/or exacerbate a wide range of comorbidities [7-9], including insulin resistance and type 2 diabetes mellitus (T2DM) [10,11], dyslipidemia [12,13], hypertension [14,15], cardiovascular disease [16,17], nonalcoholic fatty liver disease [18,19], reproductive dysfunction [20-22], and cancer [23,24]. As a result, obesity causes adverse effects on the quality of life and has marked economic consequences relating to increased healthcare costs $[25,26]$. In view of the prevalence of obesity, health consequences, and healthcare costs, there has been substantial interest in identifying effective and safe interventions/strategies to reduce excess body weight/fat in obese people. 
Although there are many factors that influence obesity and various interventions to treat it [27], a large body of evidence has demonstrated that dietary interventions/strategies are an effective and safe way to prevent or manage obesity [28-31]. As one of the micronutrients in the diet, calcium regulates many cellular processes, such as cell proliferation [32], differentiation [33], and bone formation [34]. In addition, dietary calcium has been implicated to be involved in prevention or treatment of obesity [35-40]. Onakpoya et al. reported the efficacy of calcium supplementation for management of overweight people and aimed to clarify the treatment effect of calcium supplementation in obese people [36]. Soares et al. mainly demonstrated the effect of calcium and vitamin D on obesity [41]. Barba and Russo's review focused on the association between dairy product consumption and body weight regulation in humans [40].These studies mainly focused on humans or the anti-obesity effect of calcium on overweight people. At present, there are few comprehensive reviews describing the anti-obesity effects of calcium in different models and the underlying mechanisms. In this review, we compile the evidence for the anti-obesity effects of calcium in cell models, animals, and humans and summarize the possible mechanisms by which calcium elicits its anti-obesity effects.

\section{The Anti-Obesity Effects of Calcium Supplementation}

\subsection{Inhibition of Adipogenic Differentiation by Calcium in Cell Models}

Expanded fat mass can result from increased adipocyte number (adipogenesis or hyperplasia) and/or increased adipocyte size (hypertrophy) [42]. A decrease in adipogenesis and lipogenesis and/or an increase in lipolysis contribute to fewer adipocyte number and smaller adipocyte size, thus leading to a reduction in fat accumulation. It has been reported that high extracellular calcium $\left(\left[\mathrm{Ca}^{2+}\right]_{0}\right.$, 5 and $10 \mathrm{mM}$ ) attenuates adipogenesis in 3T3-L1 preadipocytes [43]. Similarly, $5 \mathrm{mM}\left[\mathrm{Ca}^{2+}\right]_{o}$ and increased intracellular calcium $\left(\left[\mathrm{Ca}^{2+}\right]_{\mathrm{i}}\right)$ with RyR channel excitomotor caffeine significantly reduced the intracellular lipid content in the primary preadipocytes of mice [44,45]. In addition, increasing $\left[\mathrm{Ca}^{2+}\right]_{\mathrm{i}}$ was able to inhibit early stages of adipogenic differentiation in human preadipocytes [46]. Taken together, these in vitro data indicate that direct treatment of murine and human preadipocytes with calcium or calcium channel regulators could elicit inhibitory effects on adipogenic differentiation.

\subsection{Anti-Obesity Effects of Dietary Calcium in Animals}

Accumulating evidence has demonstrated that dietary calcium supplementation elicits anti-obesity effects on various animals. Our study has indicated that calcium supplementation $(0.6 \% w / w)$ in drinking water leads to significant decrease in body weight, body fat content, and inguinal white adipose tissue (iWAT) and epididymal WAT (eWAT) index in high-fat diet (HFD)-induced obese mice [47]. In line with our report, Sun et al. found that dietary supplementation of $1.4 \%$ and $2.8 \%$ calcium significantly decreased the body weight gain and the fat net weight of inguinal fat pad (IFP), epididymal fat pad (EFP), and perirenal fat pad (PFP) in HFD-fed mice [45]. The anti-obesity or body-fat-lowering effects of calcium in mice have also been reported in other studies $[48,49]$. In rats, it has been shown that, compared with standard chow, calcium-supplemented chow $\left(10 \mathrm{~g} \mathrm{CaCO}_{3} / \mathrm{kg}\right.$ of chow) significantly decreased body mass and visceral adipose tissue (VAT) mass in epididymal, retroperitoneal, and mesenteric depots [50]. In agreement, dietary calcium supplementation $(10 \mathrm{~g} / \mathrm{kg})$ resulted in significant reduction of body mass, trunk fat, and total fat in early weaning Wistar rats [51]. With regard to the brown adipose tissue (BAT), it was reported that calcium-supplemented chow $(10 \mathrm{~g} / \mathrm{kg})$ had no effects on rat BAT weight compared to standard chow [52]. Collectively, these data suggest that dietary calcium intake could elicit beneficial effects on reducing body fat deposition in murine models.

\subsection{Anti-Obesity Effects of Dietary Calcium in Humans}

Many studies have evaluated the effects of dietary calcium supplementation on body weight/fat loss in humans $[38,39,53,54]$. According to a survey, people in both developed and lesser developed 
countries have inadequate calcium intake [35]. The 2011 Institute of Medicine Dietary Reference Intake committee set the recommended dietary allowances at $1300 \mathrm{mg} /$ day calcium for children aged 9-18 years and 1000-1200 mg/day (varying by age) for healthy adults [55]. In fact, most American children do not yet meet these recommendations [56,57]. Thus, increasing the intake of daily calcium is the primary condition for health and may contribute to body weight/fat loss. A meta-analysis revealed the negative correlations between calcium supplementation and weight changes in children and adolescents, in adult men, and either premenopausal or old (above 60 years old) women and suggested that increasing calcium intake could reduce body weight in these subjects [53]. Specifically, it has been demonstrated that each $300 \mathrm{mg}$ increment in regular calcium intake is associated with approximately $1 \mathrm{~kg}$ less body fat in children and 2.5-3.0 kg lower body weight in adults [54]. Rosenblum et al. found that calcium and/or vitamin D supplementation contributed to a beneficial reduction of abdominal visceral adipose tissue in overweight and obese adults [58]. In contrast, Winzenberg et al. reported that there was no evidence to support the use of calcium supplementation as a public health intervention to reduce weight gain or body fat in healthy children [59]. It should be noted that vitamin D, which exerts a critical role in calcium absorption [60], plays an important role in influencing the anti-obesity effects of calcium. It has been reported that a deficiency of vitamin D decreases the calcium intake and increases body mass index in children and adolescents [61]. In addition, dietary calcium overdosage has been implicated in some adverse effects, including kidney stones, myocardial infarction, hypercalcemia, and hospitalization with acute gastrointestinal symptoms [62]. Excess ( $>1200 \mathrm{mg} /$ day) dietary calcium intake is related to higher Framingham Risk Score (FRS), which is generally considered as a tool to assess future cardiovascular risk in humans [63].

The source of calcium may also affect its anti-obesity effects. It has been implicated that the anti-obesity role of calcium intake in children and adolescents might be driven exclusively by dairy calcium [64], implying that dairy calcium might be more effective than calcium supplements. Consumption of a high Ca diet from dairy for 12 weeks was effective in reducing abdominal adiposity in overweight patients with T2DM [65]. Greater intake of high-fat, but not intake of low-fat, dairy products, was found to be associated with less weight gain in middle-aged and elderly women [66]. It was also reported that increasing dairy calcium intake with low-fat milk or yogurt for 12 months had no effect on decreasing body fat or weight gain in overweight adolescent girls [67]. In addition, gender may also influence the anti-obesity effects on dietary calcium. Lee et al. found that consumption of dairy products is associated with reduced risks of obesity and metabolic syndrome in Korean women but not in men [68]. Similarly, Moreira et al. reported an inverse relationship between calcium intake and BMI in only girls (7-9 years old) in Portugal [69]. The discrepancy in the effects of calcium on body weight/fat loss might result from the different subjects, calcium intake amounts, calcium sources, and calcium intake periods. Thus, due to the various influencing factors, the anti-obesity effects of dietary calcium need to be further studied in different subjects.

\section{Possible Mechanisms for Calcium's Anti-Obesity Effects}

\subsection{Effects of Calcium on Adipogenesis}

Adipogenesis includes the commitment of mesenchymal stem cells (MSCs) to the adipocyte lineage (preadipocytes) and the terminal differentiation of preadipocytes to mature adipocytes. It is tightly regulated by various signaling molecules and several key adipogenic transcription factors, such as PPAR $\gamma$ and $\mathrm{C} / \mathrm{EBP} \alpha$ [70]. It has been demonstrated that adipogenesis or hyperplasic adipose expansion is linked to anti-obesity and improved metabolic health [70-72]. A large body of evidence has demonstrated that calcium is involved in regulating adipogenesis. Jensen et al. found that high $\left[\mathrm{Ca}^{2+}\right]_{\mathrm{o}}(5$ and $10 \mathrm{mM}$ ) inhibited the adipogenesis of 3T3-L1 preadipocytes compared to controls $\left(1.8 \mathrm{mM}\left[\mathrm{Ca}^{2+}\right]_{0}\right)$, with decreased expression of PPAR $\gamma$ and C/EBP $\alpha$ [43]. Similarly, it has been reported that increased $\left[\mathrm{Ca}^{2+}\right]_{i}$ with RyR channel excitomotor caffeine significantly suppresses adipogenesis of mice preadipocytes, with decreased lipid content and PPAR $\gamma$ expression [44]. However, Shi et al. 
demonstrated that increasing $\left[\mathrm{Ca}^{2+}\right]_{\mathrm{i}}$ appeared to exert a biphasic regulatory effect on human adipocyte differentiation, inhibiting the early stages while promoting the late stage of differentiation and lipid filling [46]. We also found that high $\left[\mathrm{Ca}^{2+}\right]_{\mathrm{o}}(4 \mathrm{mM})$ stimulated adipogenesis of porcine bone marrow MSCs (pBMSCs) by increasing the $\left[\mathrm{Ca}^{2+}\right]_{i}$ level and activating CaMKII and PI3K/Akt-FoxO1 pathways [47]. We further determined that the promotive effects of $\left[\mathrm{Ca}^{2+}\right]_{\mathrm{o}}$ on pBMSCs occurred mainly in the commitment phase but not in the terminal differentiation phase (unpublished data). In line with our results, it has been indicated that high $\left[\mathrm{Ca}^{2+}\right]_{0}$ enhances adipogenic differentiation of mice BMSCs $[73,74]$ and stimulates adipogenesis of porcine synovium-derived MSCs [75]. These findings imply that calcium stimulates the early stage (commitment stage) and suppresses the late stage (terminal differentiation stage) of adipogenesis. Taken together, calcium may elicit inhibitory or stimulatory effects on adipogenesis in vitro depending on the calcium concentration, cell types, and culture systems.

Compared with the in vitro findings, the in vivo data may better reflect the role of calcium in adipogenesis. In agreement with the enhanced adipogenesis in pBMSCs, we found that calcium supplementation stimulated adipogenesis in mice fed with HFD, with increased adipocyte number and PPAR $\gamma$ expression in inguinal subcutaneous white adipose tissue [47]. Similarly, Zhang et al. found that calcium propionate supplementation in the diet of Wagyu steers could trigger upregulation of PPAR $\gamma$ and CEBP $\alpha$ mRNA expression levels, which could cause long-term activation of adipogenesis [76]. Our unpublished study also demonstrated that dietary supplementation of $1 \%$ calcium propionate significantly increased expression of adipogenesis marker genes, such as PPAR $\gamma$ and CEBP $/ \alpha$, in the backfat of finishing pigs. It should be noted that while enhanced adipogenesis in vitro is always accompanied by elevated lipid content, increased adipogenesis (or adipocyte number) in vivo does not mean more fat deposition. In fact, we found that the adipocyte diameter/size in calcium-supplemented mice was much smaller than that of HFD-fed mice. As a result, the WAT index, body fat content, and body weight were significantly reduced by calcium supplementation [47]. In agreement with this, dietary calcium supplementation $(10 \mathrm{~g} / \mathrm{kg})$ significantly inhibited adipocytes hypertrophy, with a remarkable decrease in adipocyte area in VAT of rats [50]. Similarly, dietary calcium supplementation significantly decreased the lipid droplet sectional area in rat BAT [52]. Therefore, dietary calcium can not only stimulate adipogenesis (or hyperplasia) but also inhibit adipocyte hypertrophy (adipocyte size) in vivo.

\subsection{Effects of Calcium on Fat Metabolism}

Fat metabolism in adipocyte involving the synthesis and degradation of fat (or triglyceride, TG) contributes to the hypertrophy (increase in size) and atrophy (decrease in size) of adipocytes, respectively [42]. Therefore, suppression of fat synthesis and/or promotion of fat breakdown will result in smaller adipocytes and thus less fat deposition. It has been implicated that an increase in dietary calcium intake attenuates diet-induced adiposity by modulating adipocyte intracellular $\mathrm{Ca}^{2+}$ and thereby coordinately inhibiting lipogenesis and accelerating lipolysis [77]. Sun et al. reported that high $\left[\mathrm{Ca}^{2+}\right]_{o}$ or $\left[\mathrm{Ca}^{2+}\right]_{\mathrm{i}}$ leads to reduced intracellular lipid content and decreased expression of lipogenesis genes, such as FAS and LPL, and increased expression of lipolysis gene HSL [44,45]. Meanwhile, the store-operated $\mathrm{Ca}^{2+}$ entry (SOCE) induced the phosphorylation of HSL and increased the pHSL/HSL ratio by the activation of cAMP-PKA pathway in 3T3-L1 cells [78]. Consistent with this, dietary supplement with calcium had a protective effect against HFD-induced obesity in mice by enhancing the expression of HSL [45]. In addition, it was reported that high calcium diet significantly decreased the FAS activity and triglyceride level and increased lipolytic activity with an elevated level of glycerol content in adipose tissue of male Wistar rats, thus leading to lower adiposity index [79]. Furthermore, dietary calcium supplementation during maternal pregnancy and lactation decreased the mRNA expression of FAS and SREBP-1c in the adipose tissue of adult female offspring [80]. Collectively, calcium may elicit its anti-obesity role by modulating fat metabolism, with decreased fat synthesis and increased fat breakdown. 


\subsection{Effects of Calcium on Adipocyte (Precursor) Proliferation and Apoptosis}

It has been demonstrated that calcium is involved in regulating proliferation of preadipocytes or MSCs. We observed that the enhanced proliferation of pBMSCs induced by high extracellular calcium was associated with the activation of the calcium-sensing receptor (CaSR) and ERK signaling pathway [32]. Similarly, Rocha et al. found that activation of CaSR elevated proliferation of LS14 preadipocytes [81]. In addition, the pro-proliferation effects of $\left[\mathrm{Ca}^{2+}\right]_{\mathrm{o}}$ have been reported in rat bone marrow-derived progenitor cells [82] and porcine synovium-derived mesenchymal stromal cells [75]. It should be noted that different species, cell types, and/or culture conditions (e.g., calcium concentrations) will cause different proliferative effects of calcium. We found that $\left[\mathrm{Ca}^{2+}\right]_{\mathrm{o}}$ promoted pBMSCs proliferation when $\left[\mathrm{Ca}^{2+}\right]_{0}$ was greater than or equal to $4 \mathrm{mM}$ [32]. In contrast, Liu et al. reported that the optimal $\left[\mathrm{Ca}^{2+}\right]_{\mathrm{o}}$ for rabbit BMSCs to proliferate was $1.8 \mathrm{mM}$ and that a higher level of $\left[\mathrm{Ca}^{2+}\right]_{\mathrm{o}}$ did not change cell proliferation [83]. In addition, it was shown that low calcium $(0.09 \mathrm{mM})$ greatly enhanced the growth rate and extended the lifespan of human adipose-derived MSCs [84].

Regulation of the adipocyte number by stimulating apoptotic cell death is emerging as a potential strategy for prevention and treatment of obesity. Calcium has been implicated to be linked with apoptosis [85]. It has been shown that a sustained increase in intracellular $\mathrm{Ca}^{2+}$ triggers apoptotic cell death and that $\mathrm{Ca}^{2+}$-mediated apoptosis can be induced in mature adipocytes [86]. Consistent with this, it was reported that high vitamin D and calcium intake activated the $\mathrm{Ca}^{2+}$-mediated apoptotic pathway in the adipose tissue of diet-induced obese mice, thus leading to reduced adiposity [49]. In addition, it was shown that calcium caused apoptosis in undifferentiated human adipose tissue-derived MSCs [80]. In contrast, Jensen et al. found that treatment of 3T3-L1 cells with high $\left[\mathrm{Ca}^{2+}\right]_{\mathrm{o}}$ did not significantly affect cell number or viability and did not trigger apoptosis [43]. The distinct effects of calcium on apoptosis in MSCs and 3T3-L1 might be due to the different cell types, culture systems, and calcium concentrations. Besides that, promoting the autophagy of adipocyte cells might also play a part in anti-obesity. The relationship between calcium signals and autophagy was reviewed by Bootman et al. [87]. In this review, they summarized that Calcium $\left(\mathrm{Ca}^{2+}\right)$ and $\mathrm{Ca}^{2+}$ channels have been shown to control various stages of autophagic flux. In addition, activation of calcium-sensing receptor (CaSR) induced autophagy in LS14 and SW872 preadipocyte cell lines as well as primary human preadipocytes [88]. Taken together, calcium-induced apoptosis of adipocyte (precursor) might contribute to the beneficial effects of calcium on body weight/fat loss.

\subsection{Effects of Calcium on Thermogenesis}

One of the possible mechanisms by which calcium decreases body fat is enhancing thermogenesis/energy expenditure. Calcium has been implicated to be involved in the regulation of energy balance [89]. It has been well documented that brown adipocytes and beige/brite adipocytes are enriched with uncoupling protein 1 (UCP1) and contributors to thermogenesis/heat production and are thus beneficial for body fat loss [90-92]. Conceicao et al. reported that dietary calcium supplementation was able to improve BAT thermogenesis capacity in adult rats that were overfed earlier during lactation [52]. In line with the result, our findings demonstrated that calcium supplementation significantly increased BAT thermogenesis in HFD-fed mice, with higher temperature of interscapular BAT (BAT) and elevated expression of thermogenesis related genes, such as UCP1 and peroxisome proliferator-activated receptor coactivator $1 \alpha$ (PGC1- $\alpha)$ in iBAT [93]. Accordingly, the induction of thermogenic genes in response to $\beta$-adrenergic receptor stimulation was suppressed by reduced intracellular calcium in the brown adipocytes of wild-type mice [94]. In contrast, increased intracellular calcium via transient receptor potential vanilloid 2 (TRPV2) facilitated UCP1 expression and heat production [95]. It has been implicated that the calcium-promoted thermogenic capacity of brown adipocytes may be attributed to the increased mitochondrial fusion and mitochondrial-endoplasmic reticulum contacts induced by calcium [96].

However, Parra et al. found that dairy calcium (12 g/kg diet) intake had no effects on UCP1 expression in BAT and UCP2 expression in WAT of mice and suggested that activation of thermogenesis is not involved [97]. In addition, it was reported that calcium solely after the induction phase of 
differentiation specifically suppressed gene expression of UCP1, PR domain zinc-finger protein 16 (PRDM16), and PGC1- $\alpha$ [34]. The inconsistent effect of calcium on BAT activation or thermogenesis might be due to the various animal/cell models, calcium doses, and calcium intake durations. Among these factors, calcium dose might be the most important one contributing to the variability.

With regard to calcium and WAT browning, it has been shown that sarco/endoplasmic reticulum $\mathrm{Ca}^{2+}$-ATPase $2 \mathrm{~b}$ (SERCA2b)-mediated calcium cycling can regulate thermogenesis in beige adipocytes [98]. We also found that calcium supplementation in drinking water was able to boost WAT browning, with significantly elevated expression of thermogenesis related genes, including UCP1, PRDM16, and PGC1- $\alpha$ [93]. Taken together, the current evidence suggests that calcium is involved in enhancing thermogenesis by stimulating BAT activation and WAT browning.

\subsection{Effects of Calcium on Fat Absorption and Fecal Fat Excretion}

Decreased fat absorption and increased fecal fat excretion constitute a primary determinant accounting for prevention or treatment of obesity. In animals, it has been demonstrated that high calcium intake depresses fat digestion and absorption in veal calves [99,100]. In addition, at very low concentrations of calcium, the hamster jejunum produced very few chylomicrons, suggesting reduced fat absorption [101]. Furthermore, it has been reported that a high-calcium (2.4\%) diet increases fecal excretion of dietary lipid, which might partly contribute to the reduced body fat content in rats [102]. Moreover, Ayala-Bribiesca et al. found that cheddar-type cheeses enriched with calcium led to more abundant calcium soaps, a quantitative index for fecal fatty acids, in rat feces, suggesting elevated fecal fat excretion [103].

In humans, it has been shown that supplementation of calcium decreases fat absorption and increases the fecal excretion of insoluble calcium soaps with fatty acids [104]. Similarly, a short-term increase in dietary calcium intake promoted fecal fat and energy excretion [105]. Increasing calcium intake from low-fat dairy products by $1600 \mathrm{mg} /$ day for seven days doubled the total fat excretion, with no effect on the excretion of bile acids [106]. Christensen et al. estimated that increasing the dairy calcium intake by $1241 \mathrm{mg} /$ day resulted in an increase in fecal fat of $5.2 \mathrm{~g} /$ day [107]. In addition, it was reported that supplementation of dairy calcium in conjunction with orlistat augmented fecal fat excretion [108]. Furthermore, oral supplementation of elemental calcium as calcium carbonate dose-dependently increased the percentage of fecal fat secretion to fat intake in men [109]. Moreover, short-term dietary calcium fortification ( $2200 \mathrm{mg} /$ day total and $550 \mathrm{mg}$ calcium citrate malate) significantly increased dietary saturated fat excreted from $6 \%$ to $13 \%$ in men [110]. It has been implicated that the formation of insoluble calcium soaps and the alteration of the interfacial organization of hydrolyzed lipids are involved in calcium-induced decreased fat digestion and absorption and increased fecal fat secretion [111,112]. Taken together, the beneficial roles of calcium in decreasing fat absorption and increasing fecal fat excretion might be responsible for its anti-obesity effects.

\subsection{Effects of Calcium on Gut Microbiota}

Emerging evidence has been highlighting an increasingly more important role of gut microbiota in the regulation of obesity [113-117]. It has been indicated that phylum-level changes in gut microbiota composition, decrease in bacterial diversity, and alterations of functional genes and metabolic activities are associated with obesity [118-120]. Thus, dietary intervention or modulation of the gut microbiota has the potential to prevent or treat obesity and obesity-related metabolic diseases [121-123].

It has been demonstrated that high-calcium diets appear to positively affect gut microbiota composition, favoring the growth of lactobacilli [124]. Similarly, Chaplin et al. showed that calcium supplementation modulates gut microbiota in a prebiotic manner, promoting a healthier metabolic profile, in dietary obese mice [48]. The authors found that calcium supplementation increased the length of the small intestine and the weight of the cecum and cecum feces. Calcium-fed mice exhibited increased levels of Bifidobacterium spp. and Bacteroides/Prevotella and decreased levels of Clostridium coccoides and Clostridium leptum [48]. In line with these results, we found that, compared with HFD-fed 
mice, supplementation of calcium in drinking water increased the community diversity and specific bacterial abundance in feces [125]. In addition, it has been reported that dietary calcium has a substantial influence on gut microbiota in pigs [126], broilers [127], laying hens [128], and white shrimp [129]. To date, the effects of dietary calcium on human gut microbiota remain largely unknown and need to be further explored. Nevertheless, the current evidence in animals suggests that dietary calcium might interfere with gut microbiota, which partly explains the beneficial effects of calcium on body weight/fat loss.

\section{Conclusions}

In this review, we compiled the evidence for the anti-obesity effects of calcium in cell models, animals, and humans. In addition, we summarized the possible anti-obesity mechanisms of calcium, including (a) regulation of adipogenesis, with stimulation on MSCs (or commitment stage) and inhibition on preadipocytes (or differentiation stage); (b) modulation of fat metabolism, with decreased fat synthesis (lipogenesis) and increased fat breakdown (lipolysis); (c) promotion of adipocyte (precursor) proliferation and/or apoptosis; (d) enhancement of thermogenesis, with increased BAT activation and WAT browning; (e) suppression of fat absorption and promotion of fecal fat excretion; and (f) modification of gut microbiota composition and diversity (Figure 1). In conclusion, the current evidence demonstrates the anti-obesity effects of calcium and suggests the potential application of dietary calcium supplementation for prevention or treatment of obesity.
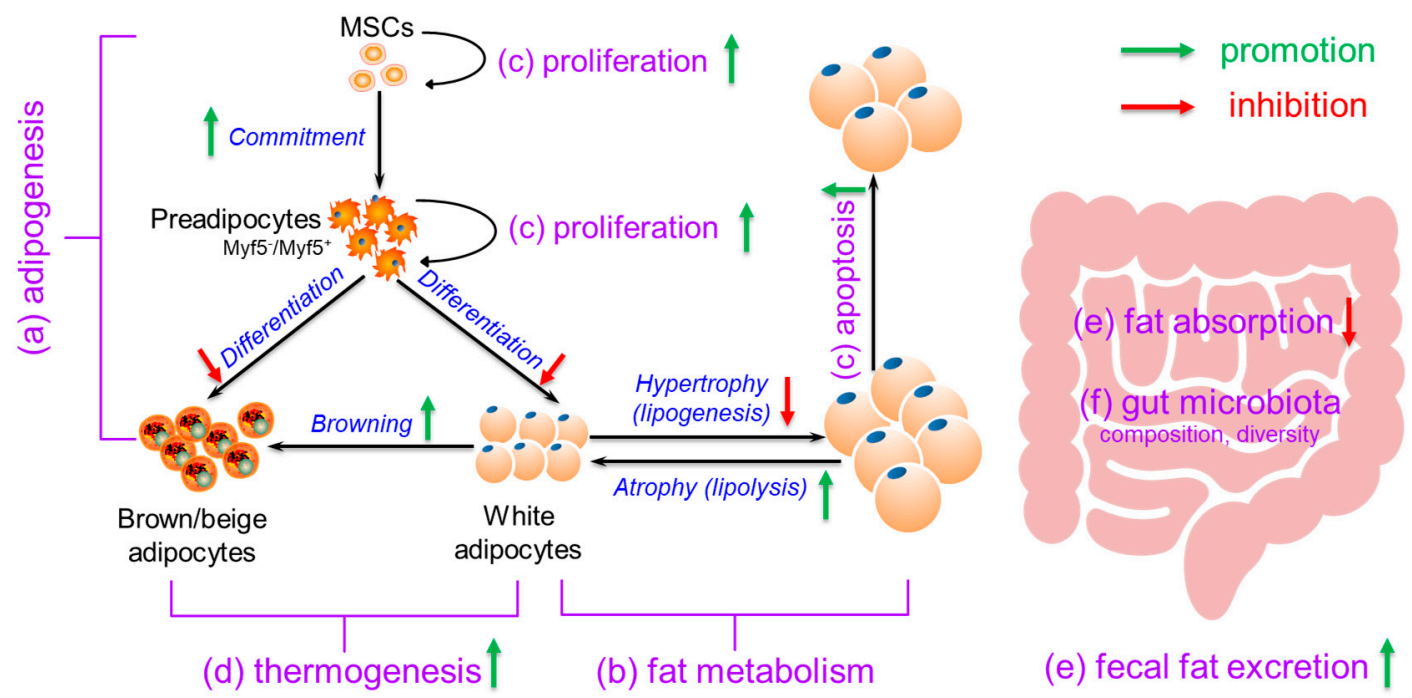

Figure 1. The possible mechanisms for the anti-obesity effects of dietary calcium. Calcium may elicit anti-obesity effects through (a) regulation of adipogenesis, with stimulation on mesenchymal stem cells (MSCs) (or commitment stage) and inhibition on preadipocytes (or differentiation stage); (b) modulation of fat metabolism, with decreased fat synthesis (lipogenesis) and increased fat breakdown (lipolysis); (c) promotion of adipocyte (precursor) proliferation and apoptosis; (d) enhancement of thermogenesis, with increased brown adipose tissue (BAT) activation and white adipose tissue (WAT) browning; (e) suppression of fat absorption and promotion of fecal fat excretion; and (f) modification of gut microbiota composition and diversity.

Author Contributions: Conceptualization, S.W.; writing—original draft preparation, F.Z. and J.Y.; writing一review and editing, F.Z., X.Z., L.W., G.S., Q.J. and S.W.; project administration, P.G.; funding acquisition, S.W., Q.J. and G.S.

Funding: This work was funded by the National Natural Science Foundation of China (31790411, 31672508, 31372397) and the Innovation team project in universities of Guangdong Province (2017KCXTD002).

Conflicts of Interest: The authors declare no conflicts of interest. 


\section{Abbreviations}

\begin{tabular}{|c|c|}
\hline BAT & brown adipose tissue \\
\hline iBAT & interscapular brown adipose tissue \\
\hline$\left[\mathrm{Ca}^{2+}\right]_{\mathrm{i}}$ & intracellular calcium \\
\hline$\left[\mathrm{Ca}^{2+}\right]_{\mathrm{o}}$ & extracellular calcium \\
\hline CaSR & calcium-sensing receptor \\
\hline $\mathrm{C} / \mathrm{EBP} \alpha$ & CCAAT/enhancer binding protein $\alpha$ \\
\hline FAS & fatty acid synthetase \\
\hline HSL & hormone sensitive lipase \\
\hline LPL & lipoprotein lipase \\
\hline MSCs & mesenchymal stem cells \\
\hline pBMSCs & porcine bone marrow mesenchymal stem cells \\
\hline PGC1- $\alpha$ & peroxisome proliferator-activated receptor coactivator $1 \alpha$ \\
\hline $\operatorname{PPAR} \gamma$ & peroxisome proliferator activated receptor $\gamma$ \\
\hline PRDM16 & PR domain zinc-finger protein 16 \\
\hline T2DM & type 2 diabetes mellitus \\
\hline TG & Triglyceride \\
\hline TRPV2 & transient receptor potential vanilloid 2 \\
\hline UCP1 & uncoupling protein 1 \\
\hline VAT & visceral adipose tissue \\
\hline WAT & white adipose tissue \\
\hline eWAT & epididymal white adipose tissue \\
\hline iWAT & inguinal white adipose tissue \\
\hline
\end{tabular}

\section{References}

1. Collaboration, N.C.D.R.F. Worldwide trends in body-mass index, underweight, overweight, and obesity from 1975 to 2016: A pooled analysis of 2416 population-based measurement studies in 128.9 million children, adolescents, and adults. Lancet 2017, 390, 2627-2642.

2. Ludwig, D.S. Epidemic childhood obesity: Not yet the end of the beginning. Pediatrics 2018, 141, e20174078. [CrossRef] [PubMed]

3. Ogden, C.L.; Carroll, M.D.; Kit, B.K.; Flegal, K.M. Prevalence of childhood and adult obesity in the United States, 2011-2012. Jama 2014, 311, 806-814. [CrossRef] [PubMed]

4. Skinner, A.C.; Ravanbakht, S.N.; Skelton, J.A.; Perrin, E.M.; Armstrong, S.C. Prevalence of obesity and severe obesity in US children, 1999-2016. Pediatrics 2018, 141, e20173459. [CrossRef] [PubMed]

5. Zhang, J.; Wang, H.; Wang, Z.; Du, W.; Su, C.; Zhang, J.; Jiang, H.; Jia, X.; Huang, F.; Ouyang, Y.; et al. Prevalence and stabilizing trends in overweight and obesity among children and adolescents in China, 2011-2015. BMC Public Health 2018, 18, 571. [CrossRef] [PubMed]

6. Wang, V.H.; Min, J.; Xue, H.; Du, S.; Xu, F.; Wang, H.; Wang, Y. What factors may contribute to sex differences in childhood obesity prevalence in China? Public Health Nutr. 2018, 21, 2056-2064. [CrossRef] [PubMed]

7. Upadhyay, J.; Farr, O.; Perakakis, N.; Ghaly, W.; Mantzoros, C. Obesity as a disease. Med. Clin. N. Am. 2018, 102, 13-33. [CrossRef] [PubMed]

8. Kyrou, I.; Randeva, H.S.; Tsigos, C.; Kaltsas, G.; Weickert, M.O. Clinical Problems Caused by Obesity. In Endotext; Feingold, K.R., Anawalt, B., Boyce, A., Chrousos, G., Dungan, K., Eds.; MDText.com, Inc.: South Dartmouth, MA, USA, 2018.

9. Bray, G.A.; Kim, K.K.; Wilding, J.P.H. Obesity: A chronic relapsing progressive disease process. A position statement of the World Obesity Federation. Obes. Rev. 2017, 18, 715-723. [CrossRef]

10. Czech, M.P. Insulin action and resistance in obesity and type 2 diabetes. Nat. Med. 2017, 23, 804-814. [CrossRef]

11. Kahn, S.E.; Hull, R.L.; Utzschneider, K.M. Mechanisms linking obesity to insulin resistance and type 2 diabetes. Nature 2006, 444, 840-846. [CrossRef]

12. Klop, B.; Elte, J.W.; Cabezas, M.C. Dyslipidemia in obesity: Mechanisms and potential targets. Nutrients 2013, 5, 1218-1240. [CrossRef] [PubMed] 
13. Howard, B.V.; Ruotolo, G.; Robbins, D.C. Obesity and dyslipidemia. Endocrinol. Metab. Clin. N. Am. 2003, 32, 855-867. [CrossRef]

14. Seravalle, G.; Grassi, G. Obesity and hypertension. Pharmacol. Res. 2017, 122, 1-7. [CrossRef] [PubMed]

15. DeMarco, V.G.; Aroor, A.R.; Sowers, J.R. The pathophysiology of hypertension in patients with obesity. Nat. Rev. Endocrinol. 2014, 10, 364-376. [CrossRef] [PubMed]

16. Ortega, F.B.; Lavie, C.J.; Blair, S.N. Obesity and Cardiovascular Disease. Circ. Res. 2016, 118, $1752-1770$. [CrossRef]

17. Mandviwala, T.; Khalid, U.; Deswal, A. Obesity and Cardiovascular Disease: A Risk Factor or a Risk Marker? Curr. Atheroscler. Rep. 2016, 18, 21. [CrossRef] [PubMed]

18. Milic, S.; Lulic, D.; Stimac, D. Non-alcoholic fatty liver disease and obesity: Biochemical, metabolic and clinical presentations. World J. Gastroenterol. 2014, 20, 9330-9337.

19. Dietrich, P.; Hellerbrand, C. Non-alcoholic fatty liver disease, obesity and the metabolic syndrome. Best Pract. Clin. Gastroenterol. 2014, 28, 637-653. [CrossRef]

20. Silvestris, E.; de Pergola, G.; Rosania, R.; Loverro, G. Obesity as disruptor of the female fertility. Reprod. Biol. Endocrinol. 2018, 16, 22. [CrossRef]

21. Dimitriadis, G.K.; Barber, T.M. Obesity-related metabolic and reproductive dysfunction: Variations between the sexes. Expert Rev. Endocrinol. Metab. 2016, 11, 387-393. [CrossRef]

22. Kahn, B.E.; Brannigan, R.E. Obesity and male infertility. Curr. Opin. Urol. 2017, 27, 441-445. [CrossRef] [PubMed]

23. Ackerman, S.E.; Blackburn, O.A.; Marchildon, F.; Cohen, P. Insights into the Link between Obesity and Cancer. Curr. Obes. Rep. 2017, 6, 195-203. [CrossRef] [PubMed]

24. Tahergorabi, Z.; Khazaei, M.; Moodi, M.; Chamani, E. From obesity to cancer: A review on proposed mechanisms. Cell Biochem. Funct. 2016, 34, 533-545. [CrossRef] [PubMed]

25. Fallah-Fini, S.; Adam, A.; Cheskin, L.J.; Bartsch, S.M.; Lee, B.Y. The Additional Costs and Health Effects of a Patient Having Overweight or Obesity: A Computational Model. Obesity 2017, 25, 1809-1815. [CrossRef] [PubMed]

26. Kim, D.D.; Basu, A. Estimating the Medical Care Costs of Obesity in the United States: Systematic Review, Meta-Analysis, and Empirical Analysis. Value Health 2016, 19, 602-613. [CrossRef] [PubMed]

27. Fruh, S.M. Obesity: Risk factors, complications, and strategies for sustainable long-term weight management. J. Am. Assoc. Nurse Pract. 2017, 29, S3-S14. [CrossRef] [PubMed]

28. Swinburn, B.A.; Caterson, I.; Seidell, J.C.; James, W.P. Diet, nutrition and the prevention of excess weight gain and obesity. Public Health Nutr. 2004, 7, 123-146. [PubMed]

29. Koliaki, C.; Spinos, T.; Spinou, M.; Brinia Mu, E.; Mitsopoulou, D.; Katsilambros, N. Defining the Optimal Dietary Approach for Safe, Effective and Sustainable Weight Loss in Overweight and Obese Adults. Healthcare 2018, 6, 73. [CrossRef] [PubMed]

30. Zulet, M.A.; Moreno-Aliaga, M.J.; Alfredo Martínez, J. Dietary determinants of fat mass and body composition. In Adipose Tissue Biology; Symonds, M.E., Ed.; Springer International Publishing: Cham, Switzerland, 2017; pp. 319-382.

31. Lai, C.S.; Wu, J.C.; Pan, M.H. Molecular mechanism on functional food bioactives for anti-obesity. Curr. Opin. Food Sci. 2015, 2, 9-13. [CrossRef]

32. Ye, J.; Ai, W.; Zhang, F.; Zhu, X.; Shu, G.; Wang, L.; Gao, P.; Xi, Q.; Zhang, Y.; Jiang, Q.; et al. Enhanced Proliferation of Porcine Bone Marrow Mesenchymal Stem Cells Induced by Extracellular Calcium is Associated with the Activation of the Calcium-Sensing Receptor and ERK Signaling Pathway. Stem Cells Int. 2016, 2016, 6570671. [CrossRef]

33. Goudarzi, F.; Mohammadalipour, A.; Khodadadi, I.; Karimi, S.; Mostoli, R.; Bahabadi, M.; Goodarzi, M.T. The Role of Calcium in Differentiation of Human Adipose-Derived Stem Cells to Adipocytes. Mol. Biotechnol. 2018, 60, 279-289. [CrossRef] [PubMed]

34. Pramme-Steinwachs, I.; Jastroch, M.; Ussar, S. Extracellular calcium modulates brown adipocyte differentiation and identity. Sci. Rep. 2017, 7, 8888. [CrossRef] [PubMed]

35. Pannu, P.K.; Calton, E.K.; Soares, M.J. Calcium and Vitamin D in Obesity and Related Chronic Disease. Adv. Food Nutr. Res. 2016, 77, 57-100. [PubMed] 
36. Onakpoya, I.J.; Perry, R.; Zhang, J.; Ernst, E. Efficacy of calcium supplementation for management of overweight and obesity: Systematic review of randomized clinical trials. Nutr. Rev. 2011, 69, 335-343. [CrossRef] [PubMed]

37. Booth, A.O.; Huggins, C.E.; Wattanapenpaiboon, N.; Nowson, C.A. Effect of increasing dietary calcium through supplements and dairy food on body weight and body composition: A meta-analysis of randomised controlled trials. Br. J. Nutr. 2015, 114, 1013-1025. [CrossRef] [PubMed]

38. Ismail, M.S.; Qahiz, N.M.A. Can Dietary Calcium Consumption be Beneficial in Body Weight Loss Regimen? Merit Res. J. Med. Med. Sci. 2016, 4, 282-289.

39. Chaturvedi, R.; Singh, N. Role of calcium in obesity: Does it help? CIBTech J. Zool. 2013, 2, 10-16.

40. Barba, G.; Russo, P. Dairy foods, dietary calcium and obesity: A short review of the evidence. Nutr. Metab. Cardiovasc. Dis. 2006, 16, 445-451. [CrossRef] [PubMed]

41. Soares, M.J.; Ping-Delfos, W.C.S.; Ghanbari, M.H. Calcium and vitamin D for obesity: A review of randomized controlled trials. Eur. J. Clin. Nutr. 2011, 65, 994-1004. [CrossRef]

42. Rutkowski, J.M.; Stern, J.H.; Scherer, P.E. The cell biology of fat expansion. J. Cell Biol. 2015, 208, 501-512. [CrossRef]

43. Jensen, B.; Farach-Carson, M.C.; Kenaley, E.; Akanbi, K.A. High extracellular calcium attenuates adipogenesis in 3T3-L1 preadipocytes. Exp. Cell Res. 2004, 301, 280-292. [CrossRef] [PubMed]

44. Sun, C.; Qi, R.; Wang, L.; Yan, J.; Wang, Y. p38 MAPK regulates calcium signal-mediated lipid accumulation through changing VDR expression in primary preadipocytes of mice. Mol. Biol. Rep. 2012, 39, 3179-3184. [CrossRef] [PubMed]

45. Sun, C.; Wang, L.; Yan, J.; Liu, S. Calcium ameliorates obesity induced by high-fat diet and its potential correlation with p38 MAPK pathway. Mol. Biol. Rep. 2012, 39, 1755-1763. [CrossRef] [PubMed]

46. Shi, H.; Halvorsen, Y.D.; Ellis, P.N.; Wilkison, W.O.; Zemel, M.B. Role of intracellular calcium in human adipocyte differentiation. Physiol. Genom. 2000, 3, 75-82. [CrossRef] [PubMed]

47. Zhang, F.; Ye, J.; Meng, Y.; Ai, W.; Su, H.; Zheng, J.; Liu, F.; Zhu, X.; Wang, L.; Gao, P.; et al. Calcium Supplementation Enhanced Adipogenesis and Improved Glucose Homeostasis Through Activation of Camkii and PI3K/Akt Signaling Pathway in Porcine Bone Marrow Mesenchymal Stem Cells (pBMSCs) and Mice Fed High Fat Diet (HFD). Cell. Physiol. Biochem. 2018, 51, 154-172. [CrossRef] [PubMed]

48. Chaplin, A.; Parra, P.; Laraichi, S.; Serra, F.; Palou, A. Calcium supplementation modulates gut microbiota in a prebiotic manner in dietary obese mice. Mol. Nutr. Food Res. 2016, 60, 468-480. [CrossRef] [PubMed]

49. Sergeev, I.N.; Song, Q. High vitamin D and calcium intakes reduce diet-induced obesity in mice by increasing adipose tissue apoptosis. Mol. Nutr. Food Res. 2014, 58, 1342-1348. [CrossRef]

50. Conceicao, E.P.; Moura, E.G.; Manhaes, A.C.; Carvalho, J.C.; Nobre, J.L.; Oliveira, E.; Lisboa, P.C. Calcium reduces vitamin D and glucocorticoid receptors in the visceral fat of obese male rats. J. Endocrinol. 2016, 230, 263-274. [CrossRef]

51. Quitete, F.T.; Nobre, J.L.; Peixoto-Silva, N.; de Moura, E.G.; Lisboa, P.C.; de Oliveira, E. Anti-obesogenic effects of calcium prevent changes in the GLP-1 profile in adult rats primed by early weaning. Mol. Nutr. Food Res. 2015, 59, 773-783. [CrossRef]

52. Conceicao, E.P.S.; Moura, E.G.; Oliveira, E.; Guarda, D.S.; Figueiredo, M.S.; Quitete, F.T.; Calvino, C.; Miranda, R.A.; Mathias, P.C.F.; Manhaes, A.C.; et al. Dietary calcium supplementation in adult rats reverts brown adipose tissue dysfunction programmed by postnatal early overfeeding. J. Nutr. Biochem. 2017, 39, 117-125. [CrossRef]

53. Li, P.; Fan, C.; Lu, Y.; Qi, K. Effects of calcium supplementation on body weight: A meta-analysis. Am. J. Clin. Nutr. 2016, 104, 1263-1273. [CrossRef]

54. Heaney, R.P.; Davies, K.M.; Barger-Lux, M.J. Calcium and weight: Clinical studies. J. Am. Coll. Nutr. 2002, 21, 152S-155S. [CrossRef] [PubMed]

55. Institute of Medicine (US) Committee to Review Dietary Reference Intakes for Vitamin D and Calcium. The national academies collection: Reports funded by national institutes of health. In Dietary Reference Intakes for Calcium and Vitamin D; Ross, A.C., Taylor, C.L., Yaktine, A.L., Del Valle, H.B., Eds.; National Academies Press (US) National Academy of Sciences: Washington, DC, USA, 2011.

56. McGuire, S. U.S. Department of Agriculture and U.S. Department of Health and Human Services, Dietary Guidelines for Americans, 2010. 7th Edition, Washington, DC: U.S. Government Printing Office, January 2011. Adv. Nutr. 2011, 2, 293-294. [CrossRef] [PubMed] 
57. Krebs-Smith, S.M.; Guenther, P.M.; Subar, A.F.; Kirkpatrick, S.I.; Dodd, K.W. Americans do not meet federal dietary recommendations. J. Nutr. 2010, 140, 1832-1838. [CrossRef] [PubMed]

58. Rosenblum, J.L.; Castro, V.M.; Moore, C.E.; Kaplan, L.M. Calcium and vitamin D supplementation is associated with decreased abdominal visceral adipose tissue in overweight and obese adults. Am. J. Clin. Nutr. 2012, 95, 101-108. [CrossRef] [PubMed]

59. Winzenberg, T.; Shaw, K.; Fryer, J.; Jones, G. Calcium supplements in healthy children do not affect weight gain, height, or body composition. Obesity 2007, 15, 1789-1798. [CrossRef] [PubMed]

60. Christakos, S.; Dhawan, P.; Porta, A.; Mady, L.J.; Seth, T. Vitamin D and intestinal calcium absorption. Mol. Cell. Endocrinol. 2011, 347, 25-29. [CrossRef] [PubMed]

61. Al-Musharaf, S.; Al-Othman, A.; Al-Daghri, N.M.; Krishnaswamy, S.; Yusuf, D.S.; Alkharfy, K.M.; Al-Saleh, Y.; Al-Attas, O.S.; Alokail, M.S.; Moharram, O.; et al. Vitamin D deficiency and calcium intake in reference to increased body mass index in children and adolescents. Eur. J. Pediatr. 2012, 171, 1081-1086. [CrossRef] [PubMed]

62. Bolland, M.J.; Grey, A.; Reid, I.R. Should we prescribe calcium or vitamin D supplements to treat or prevent osteoporosis? Climacteric 2015, 18 (Suppl. 2), 22-31. [CrossRef] [PubMed]

63. Choi, S.J.; Yeum, K.J.; Park, S.J.; Choi, B.; Joo, N.S. Dietary calcium and Framingham Risk Score in vitamin D deficient male (KNHANES 2009-2011). Yonsei Med. J. 2015, 56, 845-852. [CrossRef] [PubMed]

64. Nappo, A.; Sparano, S.; Intemann, T.; Kourides, Y.A.; Lissner, L.; Molnar, D.; Moreno, L.A.; Pala, V.; Sioen, I.; Veidebaum, T.; et al. Dietary calcium intake and adiposity in children and adolescents: Cross-sectional and longitudinal results from IDEFICS/I.Family cohort. Nutr. Metab. Cardiovasc. Dis. 2019. [CrossRef] [PubMed]

65. Gomes, J.M.G.; Costa, J.D.A.; Alfenas, R.D.C.G. Dietary calcium from dairy, body composition and glycaemic control in patients with type 2 diabetes pursuing an energy restricted diet: A parallel group randomised clinical trial. Int. Dairy J. 2017, 73, 50-56. [CrossRef]

66. Rautiainen, S.; Wang, L.; Lee, I.M.; Manson, J.E.; Buring, J.E.; Sesso, H.D. Dairy consumption in association with weight change and risk of becoming overweight or obese in middle-aged and older women: A prospective cohort study. Am. J. Clin. Nutr. 2016, 103, 979-988. [CrossRef] [PubMed]

67. Lappe, J.M.; McMahon, D.J.; Laughlin, A.; Hanson, C.; Desmangles, J.C.; Begley, M.; Schwartz, M. The effect of increasing dairy calcium intake of adolescent girls on changes in body fat and weight. Am. J. Clin. Nutr. 2017, 105, 1046-1053. [CrossRef] [PubMed]

68. Lee, K.W.; Cho, W. The Consumption of Dairy Products Is Associated with Reduced Risks of Obesity and Metabolic Syndrome in Korean Women but not in Men. Nutrients 2017, 9, 630. [CrossRef] [PubMed]

69. Moreira, P.; Padez, C.; Mourao, I.; Rosado, V. Dietary calcium and body mass index in Portuguese children. Eur. J. Clin. Nutr. 2005, 59, 861-867. [CrossRef] [PubMed]

70. Ghaben, A.L.; Scherer, P.E. Adipogenesis and metabolic health. Nat. Rev. Mol. Cell Biol. 2019, 20, $242-258$. [CrossRef] [PubMed]

71. Choe, S.S.; Huh, J.Y.; Hwang, I.J.; Kim, J.I.; Kim, J.B. Adipose Tissue Remodeling: Its Role in Energy Metabolism and Metabolic Disorders. Front. Endocrinol. 2016, 7, 30. [CrossRef]

72. Smith, U.; Kahn, B.B. Adipose tissue regulates insulin sensitivity: Role of adipogenesis, de novo lipogenesis and novel lipids. J. Int. Med. 2016, 280, 465-475. [CrossRef]

73. Hashimoto, R.; Katoh, Y.; Nakamura, K.; Itoh, S.; Iesaki, T.; Daida, H.; Nakazato, Y.; Okada, T. Enhanced accumulation of adipocytes in bone marrow stromal cells in the presence of increased extracellular and intracellular [Ca (2) (+)]. Biochem. Biophys. Res. Commun. 2012, 423, 672-678. [CrossRef]

74. Hashimoto, R.; Katoh, Y.; Miyamoto, Y.; Itoh, S.; Daida, H.; Nakazato, Y.; Okada, T. Increased extracellular and intracellular $\mathrm{Ca}(2)(+)$ lead to adipocyte accumulation in bone marrow stromal cells by different mechanisms. Biochem. Biophys. Res. Commun. 2015, 457, 647-652. [CrossRef] [PubMed]

75. Dry, H.; Jorgenson, K.; Ando, W.; Hart, D.A.; Frank, C.B.; Sen, A. Effect of calcium on the proliferation kinetics of synovium-derived mesenchymal stromal cells. Cytotherapy 2013, 15, 805-819. [CrossRef] [PubMed]

76. Zhang, X.Z.; Meng, Q.X.; Lu, L.; Cui, Z.L.; Ren, L.P. The effect of calcium propionate supplementation on performance, meat quality, and mRNA expression of finishing steers fed a high-concentrate diet. J. Anim. Feed Sci. 2015, 24, 100-106. [CrossRef]

77. Zemel, M.B. Regulation of adiposity and obesity risk by dietary calcium: Mechanisms and implications. J. Am. Coll. Nutr. 2002, 21, 146s-151s. [CrossRef] [PubMed] 
78. Maus, M.; Cuk, M.; Patel, B.; Lian, J.; Ouimet, M.; Kaufmann, U.; Yang, J.; Horvath, R.; Hornig-Do, H.T.; Chrzanowska-Lightowlers, Z.M.; et al. Store-Operated Ca (2+) Entry Controls Induction of Lipolysis and the Transcriptional Reprogramming to Lipid Metabolism. Cell Metab. 2017, 25, 698-712. [CrossRef]

79. Sandeep, D.; Dipayan, C. Role of Low Calcium and High Calcium Diet on Adipocyte Metabolism with Respect to Serum Parathyroid Hormone (PTH) Levels in Male Wistar Rats. Indian J. Physiol. Pharmacol. 2017, 61, 430-439.

80. Pesarini, J.R.; Oliveira, E.J.T.; Pessatto, L.R.; Rabacow, A.P.M.; Camassola, M.; Dos Santos, B.P.; de Barros, M.E.; Cantero, W.B.; Antoniolli-Silva, A.; Oliveira, R.J. Calcitriol combined with calcium chloride causes apoptosis in undifferentiated adipose tissue-derived human mesenchymal stem cells, but this effect decreases during adipogenic differentiation. Biomed. Pharmacother. 2018, 108, 914-924. [CrossRef]

81. Rocha, G.; Villalobos, E.; Fuentes, C.; Villarroel, P.; Reyes, M.; Diaz, X.; Mattar, P.; Cifuentes, M. Preadipocyte proliferation is elevated by calcium sensing receptor activation. Mol. Cell. Endocrinol. 2015, 412, 251-256. [CrossRef]

82. Aguirre, A.; González, A.; Planell, J.; Engel, E. Extracellular calcium modulates in vitro bone marrow-derived Flk-1+ CD34+ progenitor cell chemotaxis and differentiation through a calcium-sensing receptor. Biochem. Biophys. Res. Commun. 2010, 393, 156-161. [CrossRef]

83. Liu, Y.K.; Lu, Q.Z.; Pei, R.; Ji, H.J.; Zhou, G.S.; Zhao, X.L.; Tang, R.K.; Zhang, M. The effect of extracellular calcium and inorganic phosphate on the growth and osteogenic differentiation of mesenchymal stem cells in vitro: Implication for bone tissue engineering. Biomed. Mater. 2009, 4, 025004. [CrossRef]

84. Lin, T.M.; Tsai, J.L.; Lin, S.D.; Lai, C.S.; Chang, C.C. Accelerated growth and prolonged lifespan of adipose tissue-derived human mesenchymal stem cells in a medium using reduced calcium and antioxidants. Stem Cells Dev. 2005, 14, 92-102. [CrossRef] [PubMed]

85. Orrenius, S.; Zhivotovsky, B.; Nicotera, P. Regulation of cell death: The calcium-apoptosis link. Nat. Rev. Mol. Cell Biol. 2003, 4, 552-565. [CrossRef] [PubMed]

86. Sergeev, I.N. 1,25-Dihydroxyvitamin D3 induces $\mathrm{Ca}^{2+}$-mediated apoptosis in adipocytes via activation of calpain and caspase-12. Biochem. Biophys. Res. Commun. 2009, 384, 18-21. [CrossRef] [PubMed]

87. Bootman, M.D.; Chehab, T.; Bultynck, G.; Parys, J.B.; Rietdorf, K. The regulation of autophagy by calcium signals: Do we have a consensus? Cell Calcium 2018, 70, 32-46. [CrossRef] [PubMed]

88. Mattar, P.; Bravo-Sagua, R.; Tobar, N.; Fuentes, C.; Troncoso, R.; Breitwieser, G.; Lavandero, S.; Cifuentes, M. Autophagy mediates calcium-sensing receptor-induced TNFalpha production in human preadipocytes. Biochim. Biophys. Acta. Mol. Basis Dis. 2018, 1864, 3585-3594. [CrossRef] [PubMed]

89. Soares, M.J.; Pathak, K.; Calton, E.K. Calcium and vitamin D in the regulation of energy balance: Where do we stand? Int. J. Mol. Sci. 2014, 15, 4938-4945. [CrossRef] [PubMed]

90. Srivastava, S.; Veech, R.L. Brown and Brite: The Fat Soldiers in the Anti-obesity Fight. Front. Physiol. 2019, 10, 38. [CrossRef] [PubMed]

91. Kissig, M.; Shapira, S.N.; Seale, P. SnapShot: Brown and Beige Adipose Thermogenesis. Cell 2016, 166, 258. [CrossRef]

92. Cohen, P.; Spiegelman, B.M. Brown and Beige Fat: Molecular Parts of a Thermogenic Machine. Diabetes 2015, 64, 2346-2351. [CrossRef]

93. Zhang, F.; Su, H.; Song, M.; Zheng, J.; Liu, F.; Yuan, C.; Fu, Q.; Chen, S.; Zhu, X.; Wang, L.; et al. Calcium Supplementation Alleviates High-Fat Diet-Induced Estrous Cycle Irregularity and Subfertility Associated with Concomitantly Enhanced Thermogenesis of Brown Adipose Tissue and Browning of White Adipose Tissue. J. Agric. Food Chem. 2019. [CrossRef]

94. Sun, W.; Uchida, K.; Suzuki, Y.; Zhou, Y.; Kim, M.; Takayama, Y.; Takahashi, N.; Goto, T.; Wakabayashi, S.; Kawada, T.; et al. Lack of TRPV2 impairs thermogenesis in mouse brown adipose tissue. EMBO Rep. 2016, 17, 383-399. [CrossRef] [PubMed]

95. Sun, W.; Uchida, K.; Tominaga, M. TRPV2 regulates BAT thermogenesis and differentiation. Channels 2017, 11, 94-96. [CrossRef] [PubMed]

96. Golic, I.; Velickovic, K.; Markelic, M.; Stancic, A.; Jankovic, A.; Vucetic, M.; Otasevic, V.; Buzadzic, B.; Korac, B.; Korac, A. Calcium-induced alteration of mitochondrial morphology and mitochondrial-endoplasmic reticulum contacts in rat brown adipocytes. Eur. J. Histochem. 2014, 58, 2377. [CrossRef] [PubMed]

97. Parra, P.; Bruni, G.; Palou, A.; Serra, F. Dietary calcium attenuation of body fat gain during high-fat feeding in mice. J. Nutr. Biochem. 2008, 19, 109-117. [CrossRef] [PubMed] 
98. Ikeda, K.; Kang, Q.; Yoneshiro, T.; Camporez, J.P.; Maki, H.; Homma, M.; Shinoda, K.; Chen, Y.; Lu, X.; Maretich, P.; et al. UCP1-independent signaling involving SERCA2b-mediated calcium cycling regulates beige fat thermogenesis and systemic glucose homeostasis. Nat. Med. 2017, 23, 1454-1465. [CrossRef] [PubMed]

99. Yuangklang, C.; Wensing, T.; Van den Broek, L.; Jittakhot, S.; Beynen, A.C. Fat digestion in veal calves fed milk replacers low or high in calcium and containing either casein or soy protein isolate. J. Dairy Sci. 2004, 87, 1051-1056. [CrossRef]

100. Xu, C.; Wensing, T.; Beynen, A.C. Effects of high calcium intake on fat digestion and bile acid excretion in feces of veal calves. J. Dairy Sci. 1998, 81, 2173-2177. [CrossRef]

101. Strauss, E.W. Effects of calcium and magnesium ions upon fat absorption by sacs of everted hamster intestine. Gastroenterology 1977, 73, 421-424. [CrossRef]

102. Papakonstantinou, E.; Flatt, W.P.; Huth, P.J.; Harris, R.B. High dietary calcium reduces body fat content, digestibility of fat, and serum vitamin D in rats. Obes. Res. 2003, 11, 387-394. [CrossRef]

103. Ayala-Bribiesca, E.; Turgeon, S.L.; Pilon, G.; Marette, A.; Britten, M. Postprandial lipemia and fecal fat excretion in rats is affected by the calcium content and type of milk fat present in Cheddar-type cheeses. Food Res. Int. 2018, 107, 589-595. [CrossRef]

104. Shahkhalili, Y.; Murset, C.; Meirim, I.; Duruz, E.; Guinchard, S.; Cavadini, C.; Acheson, K. Calcium supplementation of chocolate: Effect on cocoa butter digestibility and blood lipids in humans. Am. J. Clin. Nutr. 2001, 73, $246-252$. [CrossRef] [PubMed]

105. Jacobsen, R.; Lorenzen, J.K.; Toubro, S.; Krog-Mikkelsen, I.; Astrup, A. Effect of short-term high dietary calcium intake on 24-h energy expenditure, fat oxidation, and fecal fat excretion. Int. J. Obes. 2005, 29, 292-301. [CrossRef] [PubMed]

106. Bendsen, N.T.; Hother, A.L.; Jensen, S.K.; Lorenzen, J.K.; Astrup, A. Effect of dairy calcium on fecal fat excretion: A randomized crossover trial. Int. J. Obes. 2008, 32, 1816-1824. [CrossRef] [PubMed]

107. Christensen, R.; Lorenzen, J.K.; Svith, C.R.; Bartels, E.M.; Melanson, E.L.; Saris, W.H.; Tremblay, A.; Astrup, A. Effect of calcium from dairy and dietary supplements on faecal fat excretion: A meta-analysis of randomized controlled trials. Obes. Rev. 2009, 10, 475-486. [CrossRef] [PubMed]

108. Kristensen, M.; Juul, S.R.; Sorensen, K.V.; Lorenzen, J.K.; Astrup, A. Supplementation with dairy calcium and/or flaxseed fibers in conjunction with orlistat augments fecal fat excretion without altering ratings of gastrointestinal comfort. Nutr. Metab. 2017, 14, 13. [CrossRef] [PubMed]

109. Welberg, J.W.; Monkelbaan, J.F.; de Vries, E.G.; Muskiet, F.A.; Cats, A.; Oremus, E.T.; Boersma-van Ek, W.; van Rijsbergen, H.; van der Meer, R.; Mulder, N.H.; et al. Effects of supplemental dietary calcium on quantitative and qualitative fecal fat excretion in man. Ann. Nutr. Metab. 1994, 38, 185-191. [CrossRef] [PubMed]

110. Denke, M.A.; Fox, M.M.; Schulte, M.C. Short-term dietary calcium fortification increases fecal saturated fat content and reduces serum lipids in men. J. Nutr. 1993, 123, 1047-1053.

111. Vinarova, L.; Vinarov, Z.; Tcholakova, S.; Denkov, N.D.; Stoyanov, S.; Lips, A. The mechanism of lowering cholesterol absorption by calcium studied by using an in vitro digestion model. Food Funct. 2016, 7, 151-163. [CrossRef]

112. Torcello-Gomez, A.; Boudard, C.; Mackie, A.R. Calcium Alters the Interfacial Organization of Hydrolyzed Lipids during Intestinal Digestion. Langmuir 2018, 34, 7536-7544. [CrossRef]

113. Dao, M.C.; Clement, K. Gut microbiota and obesity: Concepts relevant to clinical care. Eur. J. Int. Med. 2018, 48, 18-24. [CrossRef]

114. Federico, A.; Dallio, M.; Di Sarno, R.; Giorgio, V.; Miele, L. Gut microbiota, obesity and metabolic disorders. Minerva Gastroenterol. Dietol. 2017, 63, 337-344. [PubMed]

115. Gerard, P. Gut microbiota and obesity. Cell. Mol. Life Sci. CMLS 2016, 73, 147-162. [CrossRef] [PubMed]

116. Al-Assal, K.; Martinez, A.C.; Torrinhas, R.S.; Cardinelli, C.; Waitzberg, D. Gut microbiota and obesity. Clin. Nutr. Exp. 2018, 20, 60-64. [CrossRef]

117. Ley, R.E.; Turnbaugh, P.J.; Klein, S.; Gordon, J.I. Microbial ecology: Human gut microbes associated with obesity. Nature 2006, 444, 1022-1023. [CrossRef] [PubMed]

118. Turnbaugh, P.J.; Hamady, M.; Yatsunenko, T.; Cantarel, B.L.; Duncan, A.; Ley, R.E.; Sogin, M.L.; Jones, W.J.; Roe, B.A.; Affourtit, J.P.; et al. A core gut microbiome in obese and lean twins. Nature 2009, 457, 480-484. [CrossRef] [PubMed] 
119. Bervoets, L.; Van Hoorenbeeck, K.; Kortleven, I.; Van Noten, C.; Hens, N.; Vael, C.; Goossens, H.; Desager, K.N.; Vankerckhoven, V. Differences in gut microbiota composition between obese and lean children: A cross-sectional study. Gut Pathog. 2013, 5, 10. [CrossRef] [PubMed]

120. Pedersen, R.; Andersen, A.D.; Hermann-Bank, M.L.; Stagsted, J.; Boye, M. The effect of high-fat diet on the composition of the gut microbiota in cloned and non-cloned pigs of lean and obese phenotype. Gut Microb. 2013, 4, 371-381. [CrossRef]

121. Dror, T.; Dickstein, Y.; Dubourg, G.; Paul, M. Microbiota manipulation for weight change. Microb. Pathog. 2017, 106, 146-161. [CrossRef]

122. Brahe, L.K.; Astrup, A.; Larsen, L.H. Can We Prevent Obesity-Related Metabolic Diseases by Dietary Modulation of the Gut Microbiota? Adv. Nutr. 2016, 7, 90-101. [CrossRef]

123. Zhang, N.; Ju, Z.; Zuo, T. Time for food: The impact of diet on gut microbiota and human health. Nutrion 2018, 51-52, 80-85. [CrossRef]

124. Gomes, J.M.; Costa, J.A.; Alfenas, R.C. Could the beneficial effects of dietary calcium on obesity and diabetes control be mediated by changes in intestinal microbiota and integrity? Br. J. Nutr. 2015, 114, 1756-1765. [CrossRef] [PubMed]

125. Su, H.; Zhang, F.; Song, M.; Liu, F.; Zhu, X.; Shu, G.; Wang, L.; Gao, P.; Jiang, Q.; Wang, S. Effects of calcium chloride supplementation in drinking water on fat deposition and intestinal flora in mice fed with high-fat diet. J. South China Agric. Univ. 2019, 40, 1-5.

126. Metzler-Zebeli, B.U.; Zijlstra, R.T.; Mosenthin, R.; Ganzle, M.G. Dietary calcium phosphate content and oat beta-glucan influence gastrointestinal microbiota, butyrate-producing bacteria and butyrate fermentation in weaned pigs. FEMS Microbiol. Ecol. 2011, 75, 402-413. [CrossRef] [PubMed]

127. Borda-Molina, D.; Vital, M.; Sommerfeld, V.; Rodehutscord, M.; Camarinha-Silva, A. Insights into Broilers' Gut Microbiota Fed with Phosphorus, Calcium, and Phytase Supplemented Diets. Front. Microbiol. 2016, 7, 2033. [CrossRef] [PubMed]

128. Dastar, B.; Khosravi, A.; Boldajie, F.; Ghoorchi, T. Effect of calcium with and without probiotic, lactose, or both on organ and body weights, immune response and caecal microbiota in moulted laying hens. J. Anim. physiol. Anim. Nutr. 2016, 100, 243-250. [CrossRef] [PubMed]

129. Anuta, J.D.; Buentello, A.; Patnaik, S.; Lawrence, A.L.; Mustafa, A.; Hume, M.E.; Gatlin, D.M.; Kemp, M.C. Effect of Dietary Supplementation of Acidic Calcium Sulfate (Vitoxal) on Growth, Survival, Immune Response and Gut Microbiota of the Pacific White Shrimp, Litopenaeus vannamei. J. World Aquac. Soc. 2011, 42, 834-844. [CrossRef] 